\title{
PRELIMINARY STUDY TO EXPLORE GENE-PM 2.5 INTERACTIVE EFFECTS ON RESPIRATORY SYSTEM IN TRAFFIC POLICEMEN
}

\author{
JINZHUO ZHAO ${ }^{1}$, LIANG BO ${ }^{1}$, CHANGYI GONG ${ }^{1}$, PENG CHENG ${ }^{2}$, HAIDONG KAN ${ }^{1}$, YUQUAN XIE ${ }^{3}$, \\ and WEIMIN SONG ${ }^{1}$ \\ ${ }^{1}$ Fudan University, Shanghai, China \\ Department of Environmental Health, School of Public Health, Key Laboratory of Public Health Safety \\ ${ }^{2}$ No. 3 People's Hospital Affiliated to Shanghai Jiao Tong University School of Medicine, Shanghai, China \\ Department of Gastroenterology \\ ${ }^{3}$ Shanghai Jiao Tong University, Shanghai, China \\ Department of Cardiology, Xinhua Hospital, School of Medicine
}

\begin{abstract}
Objectives: Traffic-related particulate matter (PM) is one of the major sources of air pollution in metropolitan areas. This study is to observe the interactive effects of gene and fine particles (particles smaller than $2.5 \mu \mathrm{m}-\mathrm{PM}_{25}$ ) on the respiratory system and explore the mechanisms linking $\mathrm{PM}_{25}$ and pulmonary injury. Material and Methods: The participants include 110 traffic policemen and 101 common populations in Shanghai, China. Continuous $24 \mathrm{~h}$ individual-level $\mathrm{PM}_{25}$ is detected and the pulmonary function, high-sensitivity C-reactive protein (hs-CRP), Clara cell protein 16 (CC16) and the polymorphism in CXCL3, NME7 and C5 genes are determined. The multiple linear regression method is used to analyze the association between $\mathrm{PM}_{2.5}$ and health effects. Meanwhile, the interactive effects of gene and $\mathrm{PM}_{2.5}$ on lung function are analyzed. Results: The individual $\mathrm{PM}_{25}$ exposure for traffic policemen was higher than that in the common population whereas the forced expiratory volume in $1 \mathrm{~s}\left(\mathrm{FEV}_{1}\right)$, the ratio of $\mathrm{FEV}_{1}$ to forced vital capacity $(\mathrm{FEV} / \mathrm{FVC})$ and lymphocytes are lower. In contrast, the hs-CRP level is higher. In the adjusted analysis, $\mathrm{PM}_{2,5}$ exposure was associated with the decrease in lymphocytes and the increase in hs-CRP. The allele frequencies for NME7 and C5 have significant differences between $\mathrm{FEV}_{1} / \mathrm{FVC} \leq 70 \%$ and $\mathrm{FEV}_{1} / \mathrm{FVC}>70 \%$ participants. The results didn't find the interaction effects of gene and $\mathrm{PM}_{25}$ on $\mathrm{FEV}_{1} / \mathrm{FVC}$ in all the 3 genes. Conclusions: The results indicated that traffic exposure to high levels of $\mathrm{PM}_{2.5}$ was associated with systemic inflammatory response and respiratory injury. Traffic policemen represent a high risk group suffering from the respiratory injury.
\end{abstract}

Key words:

Inflammation, Fine particles, Traffic workers, Respiratory system, Single nucleotide polymorphism, SNP

This work was financially supported by grants from the National Natural Science Foundation of China (NSFC, grant No. 81001229, 81172617, grant manager: Jinzhuo Zhao, Ph.D., Weimin Song, M.D.) and Shanghai Municipal Health Bureau (SMHB, grant No. 2012L059A, grant manager: Yuquan Xie, Ph.D. and Natural Science Foundation of Shanghai, China (NSFSC, grant No. 09ZR1402400, grant manager: Jinzhuo Zhao, Ph.D.).

Received: June 30, 2014. Accepted: January 24, 2015.

Corresponding authors: Y. Xie, Shanghai Jiao Tong University, Xinhua Hospital, School of Medicine, Department of Cardiology, 1665 Kong Jiang Road, Shanghai, 200092 China (e-mail: xyqah@163.com); W. Song, Fudan University, School of Public Health, Department of Environment Health, Key Laboratory of Public Health Safety, 130 Dong An Road, Shanghai 200032, China (e-mail: wmsong1@gmail.com). 


\section{INTRODUCTION}

Traffic is one of the major sources of environmental particulate matter (PM) in metropolitan areas. Exposure to ambient PM, especially fine particles (particles smaller than $2.5 \mu \mathrm{m}-\mathrm{PM}_{2.5}$ ), increases daily deaths [1] and hospitalization for cardiopulmonary diseases [2,3]. However, the mechanisms linking $\mathrm{PM}_{2.5}$ and cardiopulmonary diseases remain unclear. Potential mechanisms between PM and cardiopulmonary disease have been suggested to include the increase in oxidative stress [4], inflammation [5], autonomic modulation impairment [6,7] and blood coagulation disorder [8,9]. In our previous study, individual $\mathrm{PM}_{2.5}$ exposure was associated with the systemic immune and inflammatory response in the case of traffic policemen [10]. Another study also showed that PM can act directly on many effector cells such as lymphocytes, monocytes and macrophages which are closely associated with immune and inflammatory response [11].

High-sensitivity C-reactive protein (hs-CRP), the important systemic inflammatory marker, has been found to correlate with the extent of the disease and poor lung function [12]. The increase in $\mathrm{PM}_{2.5}$ is significantly associated with the increase in hs-CRP in serum [10]. In contrast to hs-CRP systemic biomarker, Clara cell protein 16 (CC16) is known to be synthesized within respiratory tissues, including endothelial cells, Clara cells, and type II pneumocytes. The Clara cell protein 16 prevents and ameliorates lung injury in adult mice and humans [13]. Moreover, serum $\mathrm{CC} 16$ concentrations reflect alveolo-capillary membrane permeability [14]. Lower serous CC16 concentration has been detected in the case of adults with chronic obstructive pulmonary disease [15].

Currently, epidemiologic evidence regarding the relationship between pulmonary risk and traffic-related $\mathrm{PM}_{2.5}$ at the individual level is more limited. Most epidemiological studies assessed the $\mathrm{PM}_{2.5}$ exposure using the data of monitoring sites other than the individual-level $\mathrm{PM}_{2.5}[16-18]$. One study reported the association between $\mathrm{PM}_{2.5}$ exposure and immediate impairment of cardiac autonomic modulation by estimating the $24 \mathrm{~h}$ individual-level $\mathrm{PM}_{2.5}$ exposure [19]. It is generally known that gene-environment interaction leads to the development of diseases. The previous study found that the gene SLC38A8 may significantly modify the effects of occupational exposure on forced expiratory volume in $1 \mathrm{~s}\left(\mathrm{FEV}_{1}\right)$ [20]. Another study measured the individual levels of environmental tobacco smoke (ETS) using personal monitor, suggesting that subjects with different induction of CYP1A1 expression in CYP1A1 $\times 2 A$ and $C Y P 1 A 1 \times 2 A / \times 2 B$ carriers may have increased susceptibility to the genotoxic effects of ETS [21].

CXCL3 gene, belonging to chemokine family, is related to inflammatory response. Meanwhile, the previous study found that $C X C L 3$ was higher in the lung tumor tissue when compared to the matched normal tissue [22]. The function of C5 complement factor has been explored in asthma [23] and lung injures [24]. In this study, we examine the individual $\mathrm{PM}_{2.5}$ for traffic policemen and the common population and assess the association between individual $\mathrm{PM}_{2.5}$ and inflammatory response and pulmonary function. Meanwhile, the single nucleotide polymorphisms (SNPs) in CXCL3, NME7 and C5 genes are confirmed and gene$\mathrm{PM}_{2.5}$ interaction is analyzed to assess its effects on pulmonary function.

\section{MATERIAL AND METHODS}

\section{Study population and design}

The research started in 2009 and included 110 male traffic policemen and 101 common populations who are 2555 years of age from Shanghai, China. The traffic policemen mainly worked at crossroads to guide the traffic or deal with traffic accidents. The common populations work at offices for writing reports or managing documents. The 2 groups of participants work and live in 1 district of Shanghai. The participants are non-smokers and have no cardiopulmonary diseases and do not currently take medications either. The study was approved by the Human 
Studies Review Committee of the Foundation of school of public health, Fudan University. We explained the purpose of the project to all the participants and they signed an informed consent form in accordance with the relevant provisions of the Helsinki declaration. All participants declared that they had not smoked tobacco for at least 6 months prior to their participation.

All participants completed a personal history questionnaire including sociodemographic characteristics, lifestyle factors and medical history. We classified education according to the International Standard Classification of Education as total years of formal education. Four categories were defined with the highest category of $\geq 18$ years of education (equivalent to a university degree) and the lowest category of $\leq 12$ years (equivalent to a basic school degree and no vocational training). Regular alcohol intake was defined as any alcohol consumption at least 4-6 days per week.

\section{Individual $\mathrm{PM}_{2.5}$ exposure monitoring and sample collection}

A portable Air Sampler (Gilian, GilAir-3, USA) was used in combination with a $\mathrm{PM}_{2.5}$ size-selective inlet driven by a $1.5 \mathrm{l} / \mathrm{min}$ pump to obtain the individual $24 \mathrm{~h}$ mean $\mathrm{PM}_{2.5}$ exposure estimates. A sampling tube was connected with the inlet port and placed at the height which was similar with the height of breath so that it could represent the individual actual exposure. After each sampling ended, the filters were removed from the cassettes and the samples were analyzed. At the end of the study, the participants answered a recall questionnaire. Blood samples were collected to obtain serum for cell counts, hs-CRP, CC16 and SNPs detection. Serum was stored at $-80^{\circ} \mathrm{C}$. Three traffic policemen's samples or questionnaires were incomplete, thus leaving 107 participants.

\section{Pulmonary function determination}

At the end of the $24 \mathrm{~h}$ individual $\mathrm{PM}_{2.5}$ detection, the lung function was determined for all the participants at the physical examination center. The lung functions parameters of forced expiratory volume in $1 \mathrm{~s}\left(\mathrm{FEV}_{1}\right)$ and Tiffeneau index (ratio of $\mathrm{FEV}_{1}$ to forced vital capacity, $\mathrm{FEV}_{1} / \mathrm{FVC} \times 100 \%$ ) were determined.

\section{Marker of inflammation}

As a marker of inflammation, hs-CRP was measured using a 2-site chemiluminescent enzyme immunometric assay (IMMULITE hs-CRP; Diagnostic Stago Corp., CA). All analyses were performed in the Zhongshan Hospital, Fudan University. Lymphocyte, neutrophils and white blood cells were analyzed using an autoanalyzer.

\section{CC16 detection}

The CC16 was analyzed using a sandwich enzyme immunoassay (CC16 enzyme-linked immunosorbent assay (ELISA) kit; prod. DiaMed EuroGen, Turnhout, Belgium) as described by the manufacturer.

\section{Genotyping}

Genomic DNA was isolated from whole blood by means of using the Wizard Genomic DNA Purification kit (Promega) according to the manufacturer's protocol. A specific primer for CXCL3, NME7 and $C 5$ is as follows: CXCL3: FW: GGCTTTCCAGTCTCAACCAT, REV: GGCGGGACTTACATGACTTC; NME7: FW: GTCCTGACCAACCTCTTGGA, REV: GCAGTACCCCATAGACTGGTG; C5: FW: TTTCAGGACTGCTTGTAGGTGA, REV: AACTGGAGGAATGGAGTTTCC.

The SNPs investigated in the CXCL3 gene were rs170 and rs195 whereas NME7 and C5 genes were rs1457 and rs3156, respectively. The gene sequencing was facilitated by ABI 3730XL DNA analyzer. Tagging SNPs were chosen by means of using the pair-wise $\mathrm{r}^{2}$ method with an $r^{2} \geq 0.9$ and minor allele frequency $(\mathrm{MAF}) \geq 0.05-$ by means of using the SNP browser. Reproducibility was assessed by re-genotyping a random sample (5\%) of 
our population, and all genotypes matched their initially called genotype.

\section{Statistical analysis}

The entire study population consists of 101 controls and 107 traffic policemen excluding 3 participants whose samples or questionnaire surveys were incomplete. For statistical testing, a 2-sided $\mathrm{p} \leq 0.05$ were considered statistically significant. The variables were expressed as mean \pm standard deviation $(\mathrm{M} \pm \mathrm{SD})$. For statistical analysis, the differences of individual-level $\mathrm{PM}_{2.5}$ and biomarker levels between exposure and the control group were analyzed using the paired t-test.

To assess the short-term association between individual-level $\mathrm{PM}_{2.5}$ and inflammatory markers and pulmonary function, we performed multiple linear regression analyses with white blood cells, neutrophils $9(\%)$, nymphocytes (\%), $\mathrm{FEV}_{1}, \mathrm{FEV}_{1} / \mathrm{FVC}$, hs-CRP and $\mathrm{CC16}$ as the dependent variables, respectively. We entered the individual-level $\mathrm{PM}_{2.5}$ as independent variables, after adjustment for all confounding factors such as age, body mass index (BMI), categorized educational level and categorized alcohol intake, the exposure-response relationship was investigated. The total model included all the traffic policemen and common population. The exposure group model just included the traffic policemen group and the control group model just included the common population group.

All the participants including traffic policemen and the common population were divided into 2 groups according to the value of $\mathrm{FEV}_{1} / \mathrm{FVC}(\%)$. One group was defined as $\mathrm{FEV}_{1} / \mathrm{FVC}(\%) \leq 70 \%$ group and the other was defined as $\mathrm{FEV}_{1} / \mathrm{FVC}(\%)>70 \%$ group. Chi square $\left(\mathrm{Chi}^{2}\right)$ analysis was also performed to compare the allele and genotype distributions in $\mathrm{FEV}_{1} / \mathrm{FVC}(\%) \leq 70 \%$ group and $\mathrm{FEV}_{1} / \mathrm{FVC}(\%)>70 \%$ group. The multi-linear regression model was used to analyze the gene- $\mathrm{PM}_{2.5}$ interaction on $\mathrm{FEV}_{1} / \mathrm{FVC}(\%)$.

\section{RESULTS}

\section{Distribution of individual $\mathrm{PM}_{2.5}$ exposure for participants}

The concentration and distribution of individual $\mathrm{PM}_{2.5}$ for the exposure and control group were analyzed (Figure 1). The individual $\mathrm{PM}_{2.5}$ concentration was $115.4 \mu \mathrm{g} / \mathrm{m}^{3}$ (range: $32.69-217.95 \mu \mathrm{g} / \mathrm{m}^{3}$ ) and $74.96 \mu \mathrm{g} / \mathrm{m}^{3}$ (range: $\left.10.23-174.36 \mu \mathrm{g} / \mathrm{m}^{3}\right)$ in the exposure and control group, respectively (Table 1). The individual $\mathrm{PM}_{2.5}$ concentration was divided into 7 groups. The lower bound of the $\mathrm{PM}_{2.5}$ is $35 \mu \mathrm{g} / \mathrm{m}^{3}$ which is set according to the American Air Quality standards (24 h averaging time, $\mathrm{PM}_{2.5}=35 \mu \mathrm{g} / \mathrm{m}^{3}$ ). The Figure 1 shows that the majority of participants in the exposure group are exposed to high concentration of $\mathrm{PM}_{2.5}$ whereas the majority of participants in the control group are exposed to low concentration of $\mathrm{PM}_{2.5}$.

\section{Descriptive statistics of the study population}

The Table 2 described the statistics of the study population. The study population included 107 traffic policemen and 101 common populations. The differences of

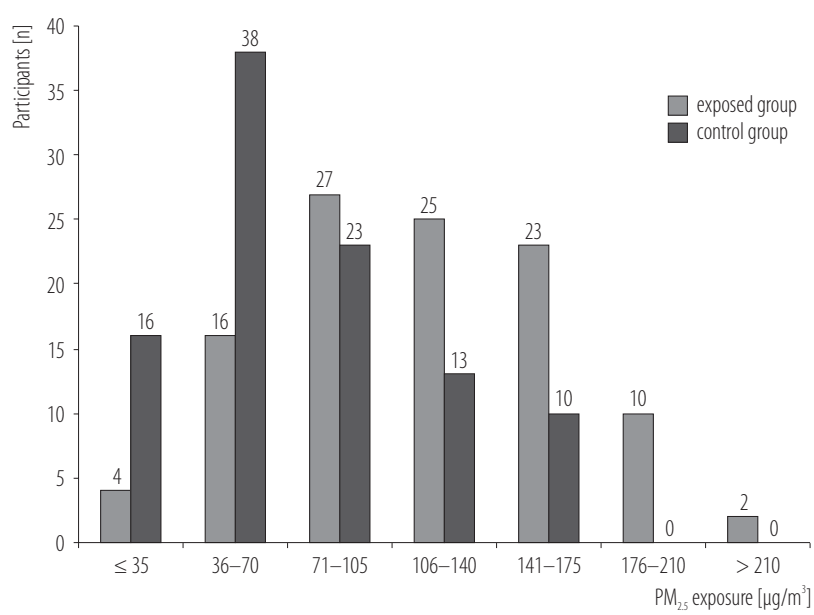

$\mathrm{PM}_{2.5}$ - particulate matter smaller than $2.5 \mu \mathrm{m}$.

The distribution was divided into 7 categories according to a progressive increase in terms of $35 \mu \mathrm{g} / \mathrm{m}^{3}$ of $\mathrm{PM}_{2.5}$ for every category.

Fig. 1. Distribution of individual particulate matter smaller than $2.5 \mu \mathrm{m}\left(\mathrm{PM}_{2.5}\right)$ exposure for 107 traffic policemen and 101 common populations 
Table 1. Average concentration of individual $24 \mathrm{~h} \mathrm{PM}_{2.5}$ exposure in study groups

\begin{tabular}{|c|c|c|c|c|}
\hline \multirow[t]{2}{*}{ Group } & \multirow{2}{*}{$\begin{array}{l}\text { Respondents } \\
{[\mathrm{n}]}\end{array}$} & \multicolumn{3}{|c|}{$\begin{array}{c}24 \mathrm{~h} \mathrm{PM}_{2.5} \text { concentration } \\
{\left[\mu \mathrm{g} / \mathrm{m}^{3}\right]}\end{array}$} \\
\hline & & $\min$. & $\max$ & $\mathrm{M} \pm \mathrm{SD}$ \\
\hline Exposed & 107 & 32.69 & 217.95 & $115.40 \pm 46.25^{* *}$ \\
\hline Control & 101 & 10.23 & 174.36 & $74.96 \pm 41.13$ \\
\hline
\end{tabular}

Min. - minimum; max - maximum; $\mathrm{M}$ - mean; SD - standard deviation.

$\mathrm{PM}_{2.5}$ - particulate matter smaller than $2.5 \mu \mathrm{g}$.

$* * \mathrm{p}<0.01$, compared with the control group.

Table 2. Descriptive statistics of the study groups

\begin{tabular}{|c|c|c|}
\hline \multirow{2}{*}{ Variable } & \multicolumn{2}{|c|}{$\begin{array}{l}\text { Study group } \\
(\mathrm{N}=208)\end{array}$} \\
\hline & $\begin{array}{c}\text { exposed } \\
(\mathrm{N}=107)\end{array}$ & $\begin{array}{c}\text { control } \\
(\mathrm{N}=101)\end{array}$ \\
\hline Age [years] $(\mathrm{M} \pm \mathrm{SD})$ & $39.33 \pm 9.23$ & $38.56 \pm 10.16$ \\
\hline $\mathrm{BMI}\left[\mathrm{kg} / \mathrm{m}^{2}\right](\mathrm{M} \pm \mathrm{SD})$ & $23.69 \pm 2.76$ & $23.41 \pm 3.69$ \\
\hline \multicolumn{3}{|l|}{ Educational time period $[\mathrm{n}(\%)]$} \\
\hline$\leq 12$ years & $31(29.0)$ & $26(25.7)$ \\
\hline $13-17$ years & $72(67.3)$ & $71(70.3)$ \\
\hline$\geq 18$ years & $4(3.7)$ & $4(4.0)$ \\
\hline Regular alcohol intake $[(\mathrm{n} \%)]$ & $54(44.8)$ & $50(44.60)$ \\
\hline $\mathrm{FEV}_{1}[1](\mathrm{M} \pm \mathrm{SD})$ & $3.53 \pm 0.63^{*}$ & $3.69 \pm 0.40$ \\
\hline $\mathrm{FEV}_{1} / \mathrm{FVC}[\%](\mathrm{M} \pm \mathrm{SD})$ & $83.57 \pm 19.16^{*}$ & $89.07 \pm 12.14$ \\
\hline $\mathrm{FEV}_{1} / \mathrm{FVC}(\%)<70 \%[\mathrm{n}(\%)]$ & $34(31.77)^{*}$ & $5(4.95)$ \\
\hline White blood cells $\left[\mathrm{n} \times 10^{9}\right](\mathrm{M} \pm \mathrm{SD})$ & $6.03 \pm 1.28$ & $5.90 \pm 1.25$ \\
\hline Neutrophils [\%] (M \pm SD) & $55.54 \pm 7.17$ & $55.58 \pm 7.18$ \\
\hline Lymphocytes [\%] (M+SD) & $34.58 \pm 6.57^{* *}$ & $37.26 \pm 7.35$ \\
\hline Hs-CRP [ $\mu \mathrm{g} / \mathrm{ml}](\mathrm{M} \pm \mathrm{SD})$ & $7.38 \pm 6.00^{*}$ & $5.60 \pm 4.04$ \\
\hline $\mathrm{CC16}[\mathrm{ng} / \mathrm{ml}](\mathrm{M} \pm \mathrm{SD})$ & $12.05 \pm 5.31$ & $12.64 \pm 4.53$ \\
\hline
\end{tabular}

BMI - body mass index; $\mathrm{FEV}_{1}$ - forced expiratory volume in $1 \mathrm{~s} ; \mathrm{FVC}$ - forced vital capacity; $\mathrm{FEV}_{1} / \mathrm{FVC}$ - ratio of FEV 1 to forced vital capacity; hs-CRP - high-sensitivity C-reactive protein; CC16 - Clara cell protein 16.

Other abbreviations as in Table 1.

$* \mathrm{p}<0.05 ; * \mathrm{p}<0.01$ compared with the control group.

inflammatory marker, blood cell counts, $\mathrm{CC16}$ and pulmonary function $\left(\mathrm{FEV}_{1}, \mathrm{FEV}_{1} / \mathrm{FVC}\right)$ between the exposure group and control group were observed. The $\mathrm{FEV}_{1}, \mathrm{FEV}_{1} /$ $\mathrm{FVC}(\%)$ and lymphocytes in the exposure group were lower than those in the control group whereas hs-CRP was higher.
There was no significant difference in white blood cell, neutrophils and $\mathrm{CC} 16$ between the 2 groups. In the exposure group, there were 34 participants whose $\mathrm{FEV}_{1}$ l FVC (\%) was in excess of $70 \%$ but there were only 5 participants in the control group. 
To understand the effects of ambient $\mathrm{PM}_{2.5}$ on pulmonary injury, the pulmonary injury-related risk factors in the exposure group and the control group were analyzed using multivariate linear regression adjusting for age, BMI, educational attainment and alcohol intake. As shown in the Table 3, the exposure group showed a higher risk suffering pulmonary dysfunction and inflammation. Forced expiratory volume in $1 \mathrm{~s}, \mathrm{FEV}_{1} / \mathrm{FVC}(\%)$ and lymphocytes were $0.140,2.360$ and 2.572 times lower in the case of the exposure group than the control group whereas hsCRP was 1.648 times higher in the case of the exposure group than the control group. White blood cell, neutrophils and CC16 had no statistical differences between the 2 groups.

\section{Individual $\mathrm{PM}_{2.5}$ exposure-response relationship}

In multiple linear regression, the association between individual $\mathrm{PM}_{2.5}$ and hs-CRP, white blood cell, neutrophils, $\mathrm{FEV}_{1}, \mathrm{FEV}_{1} / \mathrm{FVC}(\%)$ and $\mathrm{CC1} 6$ was analyzed (Table 4). In the adjusted total model, $\mathrm{PM}_{2.5}$ induced the increase in hs-CRP $(1.2 \%, 95 \%$ confidence interval (CI): $0.3-2.6)$ and decrease in lymphocytes (3.1\%, 95\% CI: 1.1-5.1).
In contrast to the findings for the above markers, there was no statistical association between individual $\mathrm{PM}_{2.5}$ and $\mathrm{FEV}_{1}, \mathrm{FEV}_{1} / \mathrm{FVC}(\%)$, white blood cell, neutrophils and $\mathrm{CC} 16$. Interestingly, it showed a statistically significant association between $\mathrm{PM}_{2.5}$ and $\mathrm{FEV}_{1} / \mathrm{FVC}(\%)$, lymphocytes, hs-CRP in the exposure group model but not in the control group model. In the exposure group model, $\mathrm{PM}_{2.5}$ exposure was associated with the increase in neutrophils and hs-CRP and decrease in $\mathrm{FEV}_{1} / \mathrm{FVC}(\%)$ and lymphocytes.

\section{Gene-PM ${ }_{2.5}$ interaction analysis}

All the participants were divided into 2 groups according to the level of $\mathrm{FEV}_{1} / \mathrm{FVC}(\%)$. One group $(\mathrm{N}=39)$ : $\mathrm{FEV}_{1} / \mathrm{FVC}(\%)<70 \%$, the other group $(\mathrm{N}=169)$ : $\mathrm{FEV}_{1} / \mathrm{FVC}(\%)>70 \%$. The distribution of SNPs of CXCL3 rs170, CXCL3 rs195, NME7 rs1457 and C5 rs3156 genes among the 2 groups was shown in the Table 5. When comparing the polymorphisms in the 2 groups, no significant difference in the CXCL3 rs170, CXCL3 rs195 allele frequencies was found. NME7 rs1457 allele frequencies were different in GG and $C 5$ rs3156 was different in $\mathrm{G}, \mathrm{A}, \mathrm{GG}$ and $\mathrm{AG}$ between the $\mathrm{FEV}_{1} / \mathrm{FVC}(\%)$

Table 3. Multivariate analysis of risk factors related to pulmonary injury between the exposure group and the control group

\begin{tabular}{|c|c|c|}
\hline Variable & $\operatorname{AOR}(95 \% \mathrm{CI})^{\mathrm{a}}$ & $\mathrm{p}$ \\
\hline $\mathrm{FEV}_{1}[\%]$ & $-0.140(-0.275-(-0.005))$ & 0.042 \\
\hline $\mathrm{FEV}_{1} / \mathrm{FVC}[\%]$ & $-2.360(-7.046-(-1.674))$ & 0.000 \\
\hline White blood cells [ $\mathrm{n} \times 10^{9}$ ] & $0.111(-0.230-0.453)$ & 0.523 \\
\hline Neutrophils [\%] & $-0.099(-2.031-1.833)$ & 0.920 \\
\hline Lymphocytes [\%] & $-2.572(-4.427-(-0.717))$ & 0.007 \\
\hline Hs-CRP $[\mu \mathrm{g} / \mathrm{ml}]$ & $1.648(0.326-2.969)$ & 0.015 \\
\hline $\mathrm{CC} 16[\mathrm{ng} / \mathrm{ml}]$ & $-1.582(-2.914-(-0.950))$ & 0.137 \\
\hline
\end{tabular}

AOR - adjusted odds ratio; $\mathrm{CI}$ - confidence interval.

Other abbreviations as in Table 2.

${ }^{a}$ Compared with the control group. The model adjusted for the age, BMI, educational time period and alcohol intake. 
Table 4. Associations of individual particulate matter smaller than $2.5 \mu \mathrm{m}\left(\mathrm{PM}_{2.5}\right)$ exposure with blood cells, pulmonary function, Clara cell protein 16 (CC16) and marker of inflammation (95\% CI)

\begin{tabular}{|c|c|c|c|c|c|c|}
\hline \multirow{2}{*}{ Variable } & \multicolumn{2}{|l|}{ Total } & \multicolumn{2}{|l|}{ Exposed group } & \multicolumn{2}{|l|}{ Control group } \\
\hline & $\operatorname{model}(\mathrm{B})^{\mathrm{a}}$ & significant & $\operatorname{model}(\mathrm{B})^{\mathrm{a}}$ & significant & $\operatorname{model}(\mathrm{B})^{\mathrm{a}}$ & significant \\
\hline $\mathrm{FEV}_{1}[\%]$ & $-0.001(-0.002-0.001)$ & 0.403 & $0.001(-0.002-0.003)$ & 0.580 & $0.000(-0.002-0.002)$ & 0.660 \\
\hline $\mathrm{FEV}_{1} / \mathrm{FVC}[\%]$ & $-0.115(-0.185-(-0.045))$ & 0.450 & $-0.050(-0.167-0.067)$ & 0.021 & $0.010(-0.029-0.048)$ & 0.231 \\
\hline $\begin{array}{l}\text { White blood } \\
\text { cells }\left[\mathrm{n} \times 10^{\circ}\right]\end{array}$ & $0.000(-0.004-0.004)$ & 0.931 & $0.000(-0.006-0.005)$ & 0.900 & $-0.002(-0.008-0.005)$ & 0.627 \\
\hline Neutrophils [\%] & $0.015(-0.005-0.036)$ & 0.149 & $0.032(0.002-0.063)$ & 0.037 & $0.004(-0.030-0.038)$ & 0.821 \\
\hline Lymphocytes [\%] & $-0.031(-0.051-(-0.011))$ & 0.003 & $-0.048(-0.075-(-0.022))$ & 0.000 & $0.006(-0.029-0.041)$ & 0.743 \\
\hline Hs-CRP $[\mu \mathrm{g} / \mathrm{ml}]$ & $0.012(0.003-0.026)$ & 0.014 & $0.016(0.009-0.040)$ & 0.025 & $0.000(-0.018-0.019)$ & 0.966 \\
\hline $\mathrm{CC} 16[\mathrm{ng} / \mathrm{ml}]$ & $-0.011(-0.026-0.003)$ & 0.113 & $0.012(-0.011-0.034)$ & 0.303 & $-0.012(-0.033-0.010)$ & 0.283 \\
\hline
\end{tabular}

Abbreviations as in Table 2 and 3.

${ }^{a}$ The model represents the sufficient adjustment set, including $\mathrm{PM}_{2.5}$, age, BMI, educational time period and alcohol intake.

Table 5. Association between polymorphism and pulmonary dysfunction

\begin{tabular}{|c|c|c|c|c|}
\hline \multirow[b]{2}{*}{ Polymorphism } & \multicolumn{4}{|c|}{ Pulmonary deficiency } \\
\hline & $\begin{array}{c}\text { respondents with } \\
\text { FEV }_{1} / \mathrm{FVC} \leq 70 \% \\
(\mathrm{~N}=39) \\
{[\mathrm{n}(\%)]}\end{array}$ & $\begin{array}{c}\text { respondents with } \\
\mathrm{FEV}_{1} / \mathrm{FVC}>70 \% \\
(\mathrm{~N}=169) \\
{[\mathrm{n}(\%)]}\end{array}$ & OR $(95 \% \mathrm{CI})$ & $\mathrm{p}$ \\
\hline CXCL3 rs170 & & & & 0.231 \\
\hline $\mathrm{A}$ & $74(94.9)$ & $331(97.9)$ & - & \\
\hline G & $4(5.1)$ & $7(2.1)$ & - & \\
\hline \multicolumn{5}{|l|}{ Genotype } \\
\hline AA & 35 (89.7) & $162(95.9)$ & $0^{\mathrm{a}}$ (reference) & \\
\hline $\mathrm{AG}$ & $4(10.3)$ & $7(4.1)$ & $3.51(-3.05-10.07)$ & 0.295 \\
\hline CXCL3 rs195 & & & & 0.539 \\
\hline A & $10(12.8)$ & $45(13.3)$ & - & \\
\hline $\mathrm{C}$ & $68(87.2)$ & $293(86.7)$ & - & \\
\hline \multicolumn{5}{|l|}{ Genotype } \\
\hline \multicolumn{5}{|l|}{ general model } \\
\hline $\mathrm{AA}$ & $1(1.3)$ & $8(4.7)$ & $0^{\mathrm{a}}$ (reference) & \\
\hline $\mathrm{AC}$ & $8(10.3)$ & $37(21.9)$ & $1.66(-1.41-1.96)$ & 0.996 \\
\hline $\mathrm{CC}$ & $30(88.4)$ & $124(73.4)$ & $1.65(-1.46-2.13)$ & 0.997 \\
\hline
\end{tabular}


Table 5. Association between polymorphism and pulmonary dysfunction - cont.

\begin{tabular}{|c|c|c|c|c|}
\hline \multirow[b]{2}{*}{ Polymorphism } & \multicolumn{4}{|c|}{ Pulmonary deficiency } \\
\hline & $\begin{array}{c}\text { respondents with } \\
\text { FEV }_{1} / \mathrm{FVC} \leq 70 \% \\
(\mathrm{~N}=39) \\
{[\mathrm{n}(\%)]}\end{array}$ & $\begin{array}{c}\text { respondents with } \\
\mathrm{FEV}_{1} / \mathrm{FVC}>70 \% \\
(\mathrm{~N}=169) \\
{[\mathrm{n}(\%)]}\end{array}$ & OR $(95 \% \mathrm{CI})$ & $\mathrm{p}$ \\
\hline \multirow{2}{*}{\multicolumn{5}{|c|}{$\begin{array}{l}\text { Genotype - cont. } \\
\text { dominant model }\end{array}$}} \\
\hline & & & & \\
\hline $\mathrm{AA}$ & $1(1.3)$ & $8(4.7)$ & $0^{\mathrm{a}}$ (reference) & \\
\hline $\mathrm{AC}+\mathrm{CC}$ & $38(97.4)$ & $161(95.3)$ & $16.5(-14.1-14.6)$ & 0.904 \\
\hline \multicolumn{5}{|l|}{ recessive model } \\
\hline $\mathrm{CC}$ & $30(88.4)$ & $124(73.4)$ & $0^{\mathrm{a}}$ (reference) & \\
\hline $\mathrm{AA}+\mathrm{AC}$ & $9(23.1)$ & 45 (26.6) & $-0.08(-2.19-2.03)$ & 0.942 \\
\hline NME7 rs1457 & & & & 0.141 \\
\hline A & $57(73.1)$ & $262(77.5)$ & - & \\
\hline $\mathrm{G}$ & $21(26.9)$ & $76(22.5)$ & - & \\
\hline \multicolumn{5}{|l|}{ Genotype } \\
\hline \multicolumn{5}{|l|}{ general model } \\
\hline $\mathrm{AA}$ & $26(66.7)$ & $101(59.8)$ & $0^{\mathrm{a}}$ (reference) & \\
\hline $\mathrm{AG}$ & $9(23.8)$ & $60(35.5)$ & $1.12(-1.08-3.33)$ & 0.318 \\
\hline GG & $4(10.3)^{* *}$ & $8(4.7)$ & $-1.24(-4.55-2.06)$ & 0.046 \\
\hline \multicolumn{5}{|l|}{ dominant model } \\
\hline $\mathrm{AA}$ & $26(66.7)$ & $101(59.8)$ & $0^{\mathrm{a}}$ (reference) & \\
\hline $\mathrm{AG}+\mathrm{GG}$ & $15(38.5)$ & $68(40.2)$ & $0.67(-1.26-2.61)$ & 0.497 \\
\hline \multicolumn{5}{|l|}{ recessive model } \\
\hline $\mathrm{GG}$ & $4(10.3)$ & $8(4.7)$ & $0^{\mathrm{a}}$ (reference) & \\
\hline $\mathrm{AG}+\mathrm{AA}$ & $33(84.6)$ & $161(95.3)$ & $1.54(-1.69-4.78)$ & 0.351 \\
\hline \multicolumn{5}{|l|}{ C5 rs 3156} \\
\hline $\mathrm{G}$ & $66(85.6)^{* *}$ & $337(99.7)$ & - & 0.000 \\
\hline A & $12(15.4)^{* *}$ & $1(0.3)$ & - & \\
\hline \multicolumn{5}{|l|}{ Genotype } \\
\hline \multicolumn{5}{|l|}{ general model } \\
\hline GG & $34(89.7)^{* *}$ & $168(99.4)$ & $0^{\mathrm{a}}$ (reference) & \\
\hline $\mathrm{AG}$ & $5(12.8)^{* *}$ & $1(0.6)$ & $-1.83(-2.41-1.74)$ & 0.032 \\
\hline
\end{tabular}

OR - odds ratio. Other abbreviations as in Table 2 and 3.

** $\mathrm{p}<0.01$ compared with $\mathrm{FEV}_{1} / \mathrm{FVC}>70 \%$ group. 
Table 6. CXCL3 single nucleotide polymorphisms (SNPs) interacting with $\mathrm{PM}_{2.5}$ exposure to affect the ratio of forced expiratory volume in $1 \mathrm{~s}$ to forced vital capacity $\left(\mathrm{FEV}_{1} / \mathrm{FVC}(\%)\right)$

\begin{tabular}{lccccc}
\hline \multicolumn{1}{c}{ Covariate } & Estimate & SE & OR & $95 \%$ CI & $\mathrm{p}$ \\
\hline $\mathrm{PM}_{2.5} \times C X C L 3$ rs170 AG & -12.09 & 16.353 & 0.044 & $-0.162-0.251$ & 0.674 \\
$\mathrm{PM}_{2.5} \times C X C L 3$ rs170 AA & $0^{\mathrm{a}}$ & & $0^{\mathrm{a}}$ & & \\
$\mathrm{PM}_{2.5} \times C X C L 3$ rs195 AC & -3.141 & 10.491 & 0.016 & $-0.198-0.230$ & 0.881 \\
$\mathrm{PM}_{2.5} \times C X C L 3$ rs195 CC & -11.310 & 11.678 & 0.082 & $-0.154-0.318$ & 0.497 \\
$\mathrm{PM}_{2.5} \times C X C L 3$ rs195 AA & $0^{\mathrm{a}}$ & & $0^{\mathrm{a}}$ & & \\
$\mathrm{PM}_{2.5} \times N M E 7$ rs1457 GG & -1.856 & 0.094 & 0.109 & $-0.075-0.294$ & 0.245 \\
$\mathrm{PM}_{2.5} \times N M E 7$ rs1457 AG & 2.272 & 0.049 & -0.040 & $-0.138-0.057$ & 0.417 \\
$\mathrm{PM}_{2.5} \times N M E 7$ rs1457 AA & $0^{\mathrm{a}}$ & & $0^{\mathrm{a}}$ & & \\
$\mathrm{PM}_{2.5} \times C 5 \mathrm{rs} 3156 \mathrm{AG}$ & -2.531 & 0.117 & 0.069 & $-0.161-0.299$ & 0.557 \\
$\mathrm{PM}_{2.5} \times C 5 \mathrm{rs} 3156 \mathrm{GG}$ & $0^{\mathrm{a}}$ & & $0^{\mathrm{a}}$ & & \\
\hline
\end{tabular}

SE - standard error. Other abbreviations as in Table 1 and 3.

${ }^{\text {a }} \mathrm{AA}$ or GG are used as reference. The model adjusted the age, BMI, educational time period and alcohol intake.

$\leq 70 \%$ and $\mathrm{FEV}_{1} / \mathrm{FVC}(\%)>70 \%$ group. In the dominant model, AA or GG acted as the reference. The results suggested that there were no differences of allele frequencies in the dominant model for all the 3 genes, and similar results were found in the recessive model.

The Table 6 showed the gene- $\mathrm{PM}_{2.5}$ interaction on $\mathrm{FEV}_{1} /$ FVC (\%). In the multiple regression analysis, after adjusting for other covariates such as age, BMI, categorized educational level and regular alcohol intake, the results couldn't find the gene- $\mathrm{PM}_{2.5}$ interaction on $\mathrm{FEV}_{1} /$ FVC (\%) for CXCL3, NME7 and C5 genes.

\section{DISCUSSION}

This study selected the traffic policemen and common populations as participants to preliminarily explore the association between individual-level $\mathrm{PM}_{2.5}$ and respiratory injury. Respiratory disease-related pulmonary function, inflammatory response and alveolo-capillary membrane permeability were determined in participants. The results indicated that the people who were exposed to high levels of $\mathrm{PM}_{2.5}$ showed a significant respiratory injury. The key finding of this study was that the increase in individuallevel $\mathrm{PM}_{2.5}$ was associated with the increase in hs-CRP and the decrease in $\mathrm{FEV}_{1}, \mathrm{FEV}_{1} / \mathrm{FVC}$ and lymphocytes. In line with the hypothesis, the results showed that effects of traffic-related $\mathrm{PM}_{2.5}$ should be stronger. Moreover, this study observed the gene- $\mathrm{PM}_{2.5}$ interaction on pulmonary function but there was no statistical significance.

Recently, most studies have investigated the acute effects of PM on acute cardiopulmonary event [25-29]. However, the biological mechanisms linking PM and cardiopulmonary diseases are still unclear. Because of their small size, $\mathrm{PM}_{2.5}$ is inhaled deeply into the lungs, with a portion depositing in the alveoli and entering the pulmonary circulation and presumably the systemic circulation [30]. In Shanghai City, $\mathrm{PM}_{2.5}$ air pollution is far in excess of the American air quality standards of $35 \mu \mathrm{g} / \mathrm{m}^{3}$ (24 $\mathrm{h}$ averaging time) and the WHO air quality guideline 
$25 \mu \mathrm{g} / \mathrm{m}^{3}$ (24 $\mathrm{h}$ averaging time). These results showed that only few traffic policemen whose individual $\mathrm{PM}_{2.5}$ exposure was lower than $35 \mu \mathrm{g} / \mathrm{m}^{3}$, and the majority of traffic policemen were exposed to high concentration of $\mathrm{PM}_{2.5}$ when compared with the common population. The results indicated that traffic-related occupational population was suffering from a very high risk of PM exposure.

One of the strengths of this study is that individual-level $\mathrm{PM}_{2.5}$ is used to explore the effects of $\mathrm{PM}_{2.5}$ on the occupational population (traffic policemen) and the common population. Previous studies always estimated PM concentration either using a simple area average of the ambient concentrations [31] or the spatial correlation based on ambient estimations at the participant's houses [18], and this data may not be representative of the individual actual exposure. In our study, $24 \mathrm{~h}$ after monitoring the individual-level $\mathrm{PM}_{2.5}$, the biological effects of $\mathrm{PM}_{2.5}$ on systemic inflammation and pulmonary function were measured for participants. Since environmental inhalation exposures such as smoking or regular exposure to biomass smoke have been shown to induce a chronic low-grade inflammatory state [32,33], our participants had been limited to non-smokers.

The multiple linear regression model was used to evaluate the association between individual-level $\mathrm{PM}_{2.5}$ and inflammatory marker, pulmonary function by adjusting for BMI, categorized educational level and regular alcohol intake. The results indicated that traffic-related $\mathrm{PM}_{2.5}$ exposure was associated with the increase in hs-CRP and decrease in $\mathrm{FEV}_{1}, \mathrm{FEV}_{1} / \mathrm{FVC}$ and lymphocytes especially in the case of traffic policemen. The result was consistent with the previous study that long-term residential exposure to high levels of $\mathrm{PM}_{2.5}$ was associated with systemic inflammatory markers [16]. In this study, traffic policemen showed higher susceptibility to $\mathrm{PM}_{2.5}$ and showed more severe systemic inflammation and pulmonary dysfunction. Along with our previous experimental study, in which $\mathrm{PM}_{2.5}$ increased the systemic hs-CRP in rats in a dose-dependent manner [34], these findings supported our hypothesis that systemic inflammation was a pathway, through which $\mathrm{PM}_{2.5}$ could lead to an acute increase in cardiopulmonary risk. This study detected lung epithelium marker CC16 to observe the effects of $\mathrm{PM}_{2.5}$ on alveolo-capillary membrane permeability. The results did not find the difference of $\mathrm{CC} 16$ between traffic policemen and the common population. Similarly, in the multi-linear regression analysis, there was no association between $\mathrm{PM}_{2.5}$ and $\mathrm{CC} 16$. The previous study showed a similar result with our findings, which found that traffic-related pollution was not consistently associated with acute changes in CC16 [35]. In this study, the relationship between $\mathrm{PM}_{2.5}$ and lung function parameters was analyzed to further explore the lung changes induced by $\mathrm{PM}_{2.5}$ exposure. The results indicated that $\mathrm{FEV}_{1}$ and $\mathrm{FEV}_{1} / \mathrm{FVC}$ were lower in the case of traffic policemen than that in the case of the common population, suggesting that traffic policemen were more possible to suffer from the poor pulmonary function. In the adjusted model, individual $\mathrm{PM}_{2.5}$ exposure was associated with the decrease in $\mathrm{FEV}_{1}$ and $\mathrm{FEV}_{1} / \mathrm{FVC}$, especially in the case of traffic policemen. Similarly, the previous study indicated that $\mathrm{PM}_{2.5}$ was associated with reductions in $\mathrm{FEV}_{1}$ [36], which supported our results. All these findings demonstrated that exposure to high concentration of $\mathrm{PM}_{2.5}$ could cause adverse respiratory effects.

The gene-environment interaction has been the major risk for a number of diseases in humans. Gene-environment studies are of special interest in the examination of cardiopulmonary injury induced by $\mathrm{PM}_{2.5}$. Identification of geneenvironment interactions could provide biological plausibility for epidemiologic observations. This study investigated gene-PM $\mathrm{P}_{2.5}$ interactions on $\mathrm{FEV}_{1} / \mathrm{FVC}(\%)$ through the SNP-level analysis. The previous study demonstrated that the low-dose $\mathrm{PM}_{2.5}$ altered the expression of 970 genes more than 2.5-fold as compared to untreated control cells, resulting in the up-regulation of 592 genes and the downregulation of 378 genes in HBE cells [37], indicating that gene expression was very important in the $\mathrm{PM}_{2.5}$-induced 
injury. The previous study found that could mediate normal and asthmatic airway smooth muscle cell migration [38], so we determined the 2 SNPs of CXCL3 to modify the relationship between $\mathrm{PM}_{2.5}$ and $\mathrm{FEV}_{1} / \mathrm{FVC}(\%)$. This study analyzed the allele and genotype distribution of CXCL3 in $\mathrm{FEV}_{1} /$ $\mathrm{FVC} \leq 70 \%$ and $\mathrm{FEV}_{1} / \mathrm{FVC}>70 \%$ groups but no significant differences were found in the 2 groups. Meanwhile, we analyzed the CXCL3-PM 2.5 interaction on $\mathrm{FEV}_{1} / \mathrm{FVC}$. However, there is no statistical significance. Similarly, this study analyzed the gene-PM $\mathrm{PM}_{2.5}$ interaction for NME7 and C5. The current results only found the allele differences of $N M E 7$ and $\mathrm{C} 5$ between $\mathrm{FEV}_{1} / \mathrm{FVC} \leq 70 \%$ and $\mathrm{FEV}_{1} / \mathrm{FVC}>70 \%$ groups but no gene-PM $\mathrm{PM}_{2.5}$ interaction was found.

\section{CONCLUSIONS}

In conclusion, this study has shown a significant association between individual $\mathrm{PM}_{2.5}$ exposure and systemic inflammatory markers and pulmonary function in the case of traffic policemen and the common population. The traffic policemen exhibited a high risk of developing pulmonary diseases and suffered from more severe lung dysfunction than common population. Although the biologic relevance of this finding is not entirely clear, the observation of note was that the systemic inflammatory response and the lung dysfunction may be induced by exposure to traffic-related $\mathrm{PM}_{2.5}$. Though we did not find the interactive effects of gene and $\mathrm{PM}_{2.5}$ on lung function, this study strengthened our confidence in exploring the gene-environment interaction on cardiopulmonary diseases in future research.

\section{REFERENCES}

1. Schwartz J, Laden F, Zanobetti A. The concentration-response relation between $\operatorname{PM}(2.5)$ and daily deaths. Environ Health Perspect. 2002;110:1025-9.

2. Bell ML, Ebisu K, Peng RD, Samet JM, Dominici F. Hospital admissions and chemical composition of fine particle air pollution. Am J Respir Crit Care Med. 2009;179:1115-20, http:// dx.doi.org/10.1164/rccm.200808-1240OC.
3. Bell ML, Ebisu K, Peng RD, Walker J, Samet JM, Zeger SL, et al. Seasonal and regional short-term effects of fine particles on hospital admissions in 202 US counties, 19992005. Am J Epidemiol. 2008;168:1301-10, http://dx.doi. org/10.1093/aje/kwn252.

4. Sorensen M, Daneshvar B, Hansen M, Dragsted LO, Hertel O, Knudsen L, et al. Personal $\mathrm{PM}_{2.5}$ exposure and markers of oxidative stress in blood. Environ Health Perspect. 2003;111:161-6.

5. Peters A, Frohlich M, Doring A, Immervoll T, Wichmann HE, Hutchinson WL. Particulate air pollution is associated with an acute phase response in men; results from the MONICA-Augsburg Study. Eur Heart J. 2001;22:1198204, http://dx.doi.org/10.1053/euhj.2000.2483.

6. Luttmann-Gibson H, Suh HH, Coull BA, Dockery DW, Sarnat SE, Schwartz J, et al. Short-term effects of air pollution on heart rate variability in senior adults in Steubenville, Ohio. J Occup Environ Med. 2006;48:780-8, http://dx.doi. org/10.1097/01.jom.0000229781.27181.7d.

7. Park JW, Lim YH, Kyung SY, An CH, Lee SP, Jeong SH. Effects of ambient particulate matter on peak expiratory flow rates and respiratory symptoms of asthmatics during Asian dust periods in Korea. Respirology. 2005;10:470-6, http://dx.doi.org/10.1111/j.1440-1843.2005.00728.x.

8. Ghio AJ, Kim C, Devlin RB. Concentrated ambient air particles induce mild pulmonary inflammation in healthy human volunteers. Am J Respir Crit Care Med. 2000;162:9818, http://dx.doi.org/10.1164/ajrccm.162.3.9911115.

9. Schwartz J. Air pollution and blood markers of cardiovascular risk. Environ Health Perspect. 2001;109 Suppl 3:405-9.

10. Zhao J, Gao Z, Tian Z, Xie Y, Xin F, Jiang R, et al. The biological effects of individual-level $\mathrm{PM}_{2.5}$ exposure on systemic immunity and inflammatory response in traffic policemen. Occup Environ Med. 2013;70:426-31, http://dx.doi. org/10.1136/oemed-2012-100864.

11. Becker S, Soukup J. Coarse (PM2.5-10), fine (PM2.5), and ultrafine air pollution particles induce/increase immune costimulatory receptors on human blood-derived 
monocytes but not on alveolar macrophages. J Toxicol Environ Health A. 2003;66:847-59, http://dx.doi. org/10.1080/15287390306381.

12. Wilson CB, Jones PW, O'Leary CJ, Hansell DM, Dowling RB, Cole PJ, et al. Systemic markers of inflammation in stable bronchiectasis. Eur Respir J. 1998;12:820-4, http:// dx.doi.org/10.1183/09031936.98.12040820.

13. Watson TM, Reynolds SD, Mango GW, Boe IM, Lund J, Stripp BR. Altered lung gene expression in CCSP-null mice suggests immunoregulatory roles for Clara cells. Am J Physiol Lung Cell Mol Physiol. 2001;281(6):L1523-30.

14. Hermans C, Knoops B, Wiedig M, Arsalane K, Toubeau G, Falmagne P, et al. Clara cell protein as a marker of Clara cell damage and bronchoalveolar blood barrier permeability. Eur Respir J. 1999;13:1014-21, http://dx.doi.org/10.1034/ j.1399-3003.1999.13e14.x.

15. Lomas DA, Silverman EK, Edwards LD, Miller BE, Coxson HO, Tal-Singer R. Evaluation of serum CC-16 as a biomarker for COPD in the ECLIPSE cohort. Thorax. 2008;63:1058-63, http://dx.doi.org/10.1136/thx.2008. 102574.

16. Baccarelli A, Martinelli I, Pegoraro V, Melly S, Grillo P, Zanobetti A, et al. Living near major traffic roads and risk of deep vein thrombosis. Circulation. 2009;119:3118-24, http:// dx.doi.org/10.1161/CIRCULATIONAHA.108.836163.

17. Hertel S, Viehmann A, Moebus S, Mann K, Brocker-Preuss M, Mohlenkamp S, et al. Influence of short-term exposure to ultrafine and fine particles on systemic inflammation. Eur J Epidemiol. 2010;25:581-92, http://dx.doi.org/10.1007/ s10654-010-9477-x.

18. Whitsel EA, Quibrera PM, Christ SL, Liao D, Prineas RJ, Anderson GL, et al. Heart rate variability, ambient particulate matter air pollution, and glucose homeostasis: The environmental epidemiology of arrhythmogenesis in the women's health initiative. Am J Epidemiol. 2009;169:693-703, http://dx.doi.org/10.1093/aje/kwn400.

19. He F, Shaffer ML, Li X, Rodriguez-Colon S, Wolbrette DL, Williams R, et al. Individual-level $\mathrm{PM}_{2.5}$ exposure and the time course of impaired heart rate variability: The APACR Study. J Expo Sci Environ Epidemiol. 2011;21:65-73, http://dx.doi.org/10.1038/jes.2010.21.

20. Liao SY, Lin X, Christiani DC. Gene-environment interaction effects on lung function - A genome-wide association study within the Framingham heart study. Environ Health. 2013;12:101, http://dx.doi.org/10.1186/1476069X-12-101.

21. Georgiadis P, Topinka J, Vlachodimitropoulos D, Stoikidou M, Gioka M, Stephanou G, et al. Interactions between CYP1A1 polymorphisms and exposure to environmental tobacco smoke in the modulation of lymphocyte bulky DNA adducts and chromosomal aberrations. Carcinogenesis. 2005;26:93-101, http://dx.doi.org/10.1093/carcin/bgh294.

22. Kowalczuk O, Burzykowski T, Niklinska WE, Kozlowski M, Chyczewski L, Niklinski J. CXCL5 as a potential novel prognostic factor in early stage non-small cell lung cancer: Results of a study of expression levels of 23 genes. Tumour Biol. 2014;35:4619-28, http://dx.doi.org/10.1007/s13277-0141605-x.

23. Staab EB, Sanderson SD, Wells SM, Poole JA. Treatment with the C5a receptor/CD88 antagonist PMX205 reduces inflammation in a murine model of allergic asthma. Int Immunopharmacol. 2014;21:293-300, http://dx.doi.org/10. 1016/j.intimp.2014.05.008.

24. Stiehm M, Bufe A, Peters M. Proteolytic activity in cowshed dust extracts induces C5a release in murine bronchoalveolar lavage fluids which may account for its protective properties in allergic airway inflammation. Thorax. 2013;68:31-8, http://dx.doi.org/10.1136/thoraxjnl-2012-201746.

25. Delfino RJ, Staimer N, Tjoa T, Polidori A, Arhami M, Gillen DL. Circulating biomarkers of inflammation, antioxidant activity, and platelet activation are associated with primary combustion aerosols in subjects with coronary artery disease. Environ Health Perspect. 2008;116:898-906, http://dx.doi. org/10.1289/ehp.11189.

26. Dubowsky SD, Suh H, Schwartz J, Coull BA, Gold DR. Diabetes, obesity, and hypertension may enhance associations 
between air pollution and markers of systemic inflammation. Environ Health Perspect. 2006;114:992-8, http://dx.doi. org/10.1289/ehp.8469.

27. Ruckerl R, Greven S, Ljungman P, Aalto P, Antoniades C, Bellander T, et al. Air pollution and inflammation (interleukin-6, C-reactive protein, fibrinogen) in myocardial infarction survivors. Environ Health Perspect. 2007;115:1072-80, http://dx.doi.org/10.1289/ehp.10021.

28. Yang X, Yue CL, Wang Q, Huang NH, Xu DQ, Liu HG. [Histopathology of lung of rats exposed to suspension of $\operatorname{PM}(2.5)$ with silver staining]. Zhonghua Lao Dong Wei Sheng Zhi Ye Bing Za Zhi. 2007;25:541-5. Chinese.

29. Smargiassi A, Goldberg MS, Wheeler AJ, Plante C, Valois MF, Mallach G, et al. Associations between personal exposure to air pollutants and lung function tests and cardiovascular indices among children with asthma living near an industrial complex and petroleum refineries. Environ Res. 2014;132:38-45, http://dx.doi.org/10.1016/j.envres.2014.03.030.

30. Furuyama A, Kanno S, Kobayashi T, Hirano S. Extrapulmonary translocation of intratracheally instilled fine and ultrafine particles via direct and alveolar macrophage-associated routes. Arch Toxicol. 2009;83:429-37, http://dx.doi. org/10.1007/s00204-008-0371-1.

31. Liao D, Duan Y, Whitsel EA, Zheng ZJ, Heiss G, Chinchilli VM, et al. Association of higher levels of ambient criteria pollutants with impaired cardiac autonomic control: A population-based study. Am J Epidemiol. 2004;159:768-77, http://dx.doi.org/10.1093/aje/kwh109.

32. Baccarelli A, Zanobetti A, Martinelli I, Grillo P, Hou L, Lanzani G, et al. Air pollution, smoking, and plasma homocysteine. Environ Health Perspect. 2007;115:176-81.
33. Ray MR, Mukherjee S, Roychoudhury S, Bhattacharya $\mathrm{P}$, Banerjee M, Siddique S, et al. Platelet activation, upregulation of $\mathrm{CD} 11 \mathrm{~b} / \mathrm{CD} 18$ expression on leukocytes and increase in circulating leukocyte-platelet aggregates in Indian women chronically exposed to biomass smoke. Hum Exp Toxicol. 2006;25:627-35, http://dx.doi. org/10.1177/0960327106074603.

34. Zhao J, Xie Y, Qian X, Jiang R, Song W. Acute effects of fine particles on cardiovascular system: Differences between the spontaneously hypertensive rats and Wistar Kyoto rats. Toxicol Lett. 2010;193:50-60, http://dx.doi.org/10.1016/j.toxlet.2009.12.002.

35. Zuurbier M, Hoek G, Oldenwening M, Meliefste K, Krop E, van den Hazel P, et al. In-traffic air pollution exposure and $\mathrm{CC} 16$, blood coagulation, and inflammation markers in healthy adults. Environ Health Perspect. 2011;119:1384-9, http://dx.doi.org/10.1289/ehp.1003151.

36. Wu S, Deng F, Hao Y, Wang X, Zheng C, Lv H, et al. Fine particulate matter, temperature, and lung function in healthy adults: Findings from the HVNR study. Chemosphere. 2014;108:168-74, http://dx.doi.org/10.1016/j.chemosphere.2014.01.032.

37. Ding X, Wang M, Chu H, Chu M, Na T, Wen Y, et al. Global gene expression profiling of human bronchial epithelial cells exposed to airborne fine particulate matter collected from Wuhan, China. Toxicol Lett. 2014;228:25-33, http://dx.doi. org/10.1016/j.toxlet.2014.04.010.

38. Al-Alwan LA, Chang Y, Mogas A, Halayko AJ, Baglole CJ, Martin JG, et al. Differential roles of CXCL2 and CXCL3 and their receptors in regulating normal and asthmatic airway smooth muscle cell migration. J Immunol. 2013;191: 2731-41, http://dx.doi.org/10.4049/jimmunol.1203421.

This work is available in Open Access model and licensed under a Creative Commons Attribution-NonCommercial 3.0 Poland License - http://creativecommons.org/ licenses/by-nc/3.0/pl/deed.en. 